\title{
Comparative study of new imaging technologies for the diagnosis of glaucoma: design and conduct of a multi-centre diagnostic accuracy study
}

\author{
Katie Banister ${ }^{1 *}$, Jonathan Cook', Craig Ramsay ${ }^{1}$, Jennifer Burr², Rodolfo Hernández', Kirsty McCormack', \\ Rupert Bourne ${ }^{3}$, Mark Batterbury ${ }^{4}$, David Garway-Heath ${ }^{5}$, Augusto Azuara-Blanco ${ }^{6}$ \\ From 2nd Clinical Trials Methodology Conference: Methodology Matters \\ Edinburgh, UK. 18-19 November 2013
}

\section{Purpose}

The detection and diagnosis of glaucoma is challenging for health professionals. In the UK, approximately $45 \%$ of patients are discharged from secondary care after one visit.

Automated imaging technologies are easy to perform and could potentially be used by trained technicians as triage tests for glaucoma diagnosis.

The GATE study aims to compare the diagnostic performance of three technologies, Heidelberg Retina Tomograph (HRT-III), Scanning laser polarimetry (GDx-ECC) and Optical Coherence Tomography (Spectralis), as triage tests in secondary care for glaucoma diagnosis.

\section{Method}

Design

Diagnostic accuracy study, comparing 3 imaging techniques for glaucoma diagnosis.

\section{Population}

Adult patients, newly referred from community to hospital eye services for suspected glaucoma.

\section{Reference standard}

Comprehensive clinical examination by experienced consultant ophthalmologist, including fundus examination and visual field tests.

\section{Sample size}

954, each imaged using all three technologies.

'University of Aberdeen, Aberdeen, UK

Full list of author information is available at the end of the article

\section{Setting}

NHS secondary care, UK.

\section{Outcomes}

Diagnostic performance measures, economic outcomes.

\section{Data collection}

Data uploaded at site via secure web-based data-collection system.

\section{Results}

Recruitment commenced April 2011. To date, 874 participants have been enrolled from five UK hospitals. GATE is an on-going research study and will be completed in November 2013.

\section{Discussion}

Conducting a multicentre diagnostic accuracy study in ophthalmology is challenging. Problems which were overcome are grouped into: difficulties in site set-up, consensus in agreeing a reference standard and agreeing study processes. Solutions were achieved through careful planning and support from site based staff.

\section{Conclusion}

Challenges in setting up and running a large diagnostic accuracy study can be overcome given adequate resource and planning. http://www.abdn.ac.uk/chart/gate.

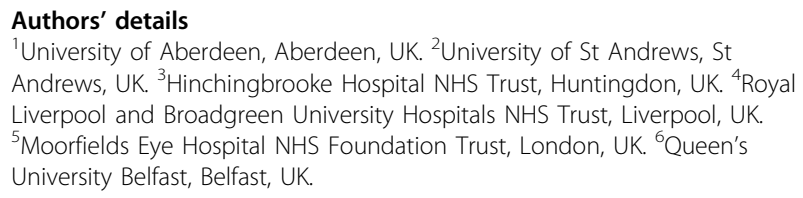


doi:10.1186/1745-6215-14-S1-045

Cite this article as: Banister et al.: Comparative study of new imaging technologies for the diagnosis of glaucoma: design and conduct of a multi-centre diagnostic accuracy study. Trials 2013 14(Suppl 1):045.

Submit your next manuscript to BioMed Central and take full advantage of:

- Convenient online submission

- Thorough peer review

- No space constraints or color figure charges

- Immediate publication on acceptance

- Inclusion in PubMed, CAS, Scopus and Google Scholar

- Research which is freely available for redistribution

Submit your manuscript at www.biomedcentral.com/submit 